\title{
Changes in Collagen Type 3, Elastin, Fibrosis and Cajal Cell in Congenital Ureteropelvic Junction Obstruction
}

\section{Üreteropelvik Bileşke Obstrüksüyonunda; Kollajen Tip 3, Elastin, Fibrozis ve Cajal Hücrelerindeki Değişiklikler}

\author{
Hasan Deliktaş1, Oktay Issı2, Abdullah Gedik3, Hayrettin Şahin1 \\ 1 Muğla Sıtkı Koçman University Faculty of Medicine, Department of Urology, Muğla, Turkey \\ 2Bingöl State Hospital, Clinic of Urology, Bingöl, Turkey \\ 3 Dicle University Faculty of Medicine, Department of Urology, Diyarbakır, Turkey
}

\begin{abstract}
What's known on the subject? and What does the study add?
Histopatology of ureteropelvic junction obstruction is not fully understood whether these histopathological changes are present from birth and result in UPJO or whether the histopatholical changes in this region develop later, associated with a mechanical obstruction. In this study, it was attempted to explain this situation by histopathological comparison of UPJ segments excised from paediatric and adult patients.
\end{abstract}

\section{ABSTRACT}

Objective

To compare changes in collagen type 3, elastin, fibrosis and cajal cells through histopathological examination of the ureteropelvic junction (UPJ) segments of pediatric and adult patients who had undergone AndersonHynes pyeloplasty for ureteropelvic junction obstruction (UPJO).

\section{Materials and Methods}

Histopathological evaluation was made of the UPJ segments of 52 patients who underwent Anderson-Hynes pyeloplasty for UPJO between January 2005 and January 2008. Patients were separated into 2 groups as pediatric, aged $\leq 15$ years (group $1, n=10$ ) and adult, aged $>15$ years (group $2, n=42$ ). UPJ segments of both groups were compared histopathologically (collagen type 3, elastin, fibrosis and cajal cells). Radiographic evaluations were made with diuretic renogram and/or intravenous pyelography.

\section{Results}

Mean age of group 1 patients was $8.12 \pm 2.6$ years ( $1-12$ years) and of group 2 patients, $38.16 \pm 5.91$ years (16-62 years). Mean follow-up period was 18 months (9-24 months). No statistically significant difference was determined between the groups in respect of collagen type 3, elastin, fibrosis or cajal cells $(p>0.05)$.

\section{Conclusion}

As the pathology in the UPJ obstruction is a congenital defect, the histopathology does not change with age.

\section{Key Words}

Ureteropelvic junction obstruction, histopathology, pediatric, adult

\section{ÖZET}

Amaç

Üreteropelvik bileşke darlığı (ÜPBD) nedeniyle Anderson-Hynes pyeloplasti yapılan pediatrik ve erişkin hastaların üreteropelvik bileşke (ÜPB) segmentlerini histopatolojik olarak incelemek ve bu hastalarda; kollajen tip 3, elastin, fibrozis ve cajal hücrelerindeki değişimleri karşılaştırmak.

\section{Gereç ve Yöntem}

Üreteropelvik bileşke darlığı nedeniyle Ocak 2005-0cak 2008 tarihleri arasında Anderson-Hynes pyeloplasti yapılan 52 hastanın ÜPB segmentleri histopatolojik olarak değerlendirildi. On beş yaş ve altı olan hastalar pediatrik grup (grup $1 ; n=10$ ), 15 yaş üstü hastalar erişkin grup (grup $2 ; n=42$ ) olmak üzere iki gruba ayrıldı. Her iki grubun ÜPB segmentleri histopatolojik (kollajen tip 3, elastin, fibrosiz ve cajal hücreleri) olarak karşılaştıııldı. Radiografik değerlendirmeler diuretik renogram ve/veya intravenöz pyelografi ile yapıldı.

\section{Bulgular}

Hastaların ortalama yaşı; grup 1 için, 8,12 2,6 (1-12 yıl), grup 2 için, $38,16 \pm 5,91$ (16-62 yıl) idi. Ortalama takip süresi 18 ay (9-24 ay) idi. Gruplar karşılaştırıldığında; kollajen tip 3, elastin, fibrozis ve cajal hücrelerinde istatistiksel fark yoktu $(p>0,05)$.

\section{Sonuç}

ÜPBD'de, üretreopelvik bileşkedeki patoloji doğumsal bir defekt olup, yaşla birlikte histopatoloji değişmez.

\section{Anahtar Kelimeler}

Üreteropelvik bileşke darlığı, cajal hücreleri, elastin, kollajen tip 3, fibrozis, pediatrik, erişkin

\section{Correspondence}

Hasan Deliktaş MD, Muğla Sıtkı Koçman University Faculty of Medicine, Department of Urology, Muğla, Turkey

Phone:+90 50575933 36 E-mail: hasandeliktas@mynet.com

Journal of Urological Surgery. 


\section{Introduction}

In children, ureteropelvic junction obstruction (UPJO) is the most frequently seen cause of urinary tract obstruction, seen at the rate of $1 / 1000-1 / 2000$ births (1). The cause of the pathology in UPJ0 remains unclear despite embryological (2), anatomical (3), functional (4) and histological (5) research. In the histopathological evaluation of UPJ, a reduction in smooth muscle cells, an accumulation of abnormal collagen and a reduction in cajal cells and neuronal elements have been determined $(6,7)$. It is not fully understood whether these histopathological changes are present from birth and result in UPJO or whether the histopatholical changes in this region develop later, associated with a mechanical obstruction. In this study, it was attempted to explain this situation by histopathological comparison of UPJ segments excised from paediatric and adult patients.

\section{Materials and Methods}

The study comprised 52 patients who underwent pyeloplasty for UPJO in our clinic between 2005 and 2008. Patients were excluded if the obstruction was associated with extrinsic causes such as aberrant vascular pressure or peri-ureteral fibrosis. The patients were separated into 2 groups as paediatric, aged $\leq 15$ years (group $1, n=10$ ) and adult, aged $>15$ years (group $2, n=42$ ). The UPJ segments of both groups were compared histopathologically (collagen type 3, elastin, fibrosis and cajal cells). Preoperative evaluations were applied to all cases with diuretic renogram and/or intravenous pyelography. Anderson-Hynes pyeloplasty was applied to all patients.

Pathological Evaluation

All excised UPJ segments were examined at Pathology Lab. Sections 4 $\mu \mathrm{m}$ thick were obtained from formalin-fixed paraffin blocks, stained with hematoxylin \&t eosin, and examined under a light microscope. Reticulin and Masson's trichrome staining was performed to determine collagen type 3 status in the submucosa and the presence of fibrosis.

\section{Immunohistochemical Method}

Cross sections $4 \mu \mathrm{m}$ thick obtained from the paraffin blocks of selected patients were transferred to positively charged slides for immunohistochemical examination using a CD117/c-kit (catalogue no. CME 296 AK Biocare Medical USA) and Elastin (catalog no. GTX29519 Genetex, Inc.USA antibodies). Sections were deparaffinized. Dehydration was performed in 96-degree ethyl alcohol and antigen recovery was carried out in a microwave oven in $\mathrm{pH} 6.0$ citrate buffer solution. The sections were cooled for $20 \mathrm{~min}$ at room temperature and kept in phosphate buffered saline (PBS) solution for $10 \mathrm{~min}$. The tissues were circled using a hydrophobic pen, and then maintained in protein block solution (Ultra $\mathrm{V}$ Block) for $5 \mathrm{~min}$. The sections were then washed with PBS and incubated for 40 min using a CD117/ckit and elastin. Next, they were washed with PBS, maintained at room temperature for 20 min with coenzyme Value Primer Antibody Enhancer, and then washed with PBS solution. Afterwards, they were treated with Value HRP Polymer for 30 min in a dark environment. They were then washed with PBS, maintained in AEC (3-amino-9ethylcarbazol) single solution, and then washed with distilled water. Contrast staining was performed for 2 min using Mayer's hematoxylin. After drying at room temperature they were covered with aqueous mounting material (Ultramount, Labvision), and then evaluated under a light microscope.

\section{Evaluation of CD117, Elastin, Masson's Trichrome, and Reticulin Staining}

Cajal cells between the muscle layers stained with CD117 were enumerated in the 10 Times Enlarging Area (TEA) and evaluated as follows: $n=0-1 \quad(-) ; n=2-5 \quad(+) ; n=6-10 \quad(++) ; n=\geq 11 \quad(+++)$. Macrophages in the mucosa and submucosa were evaluated as positive controls. Evaluation of elastin staining was positive $(+)$ or negative (-). The blood vessel wall was evaluated as a positive control. Masson's trichrome staining evaluation was performed according to fibrosis in the submucosa. Elastin couldn't be separated, as the collagen, elastin, and other connective tissues were stained blue; staining was considered positive (+) if there was blue coloring under the epithelium and negative (-) if there wasn't. Reticulin was evaluated according to the thickness of the fibers in the submucosa, as positive $(+)$ or negative $(-)$; reticulin fibers observed via low magnification were considered positive $(+)$ and those that were not were considered negative (-).

\section{Statistical Analysis}

Statistical analysis of the data was performed using SPSS v.15.0 for Windows (SPSS Inc., Chicago, IL, USA). Frequencies and means for all data in both groups were calculated. Between-group comparisons were made using the Chi-square test with Yates correction. The level of statistical significance was set at $p<0.05$.

\section{Results}

The mean age of group 1 patients was $8.12 \pm 2.6$ years ( $1-12$ years) and of group 2 patients, $38.16 \pm 5.91$ years (16-62 years). No statistically significant difference was determined between the groups in respect of collagen type 3 , elastin, fibrosis or cajal cells ( $p>0.05)$ (Table 1 , Figure 1). The mean follow-up period was 18 months (9-24 months).

\section{Discussion}

The cause of congenital ureteropelvic junction obstruction is not fully known. Several studies have suggested that congenital obstruction in the uteropelvic junction originates from changes in the structure of collagen and smooth muscle cells (7).

\begin{tabular}{|l|l|l|l|l|}
\hline \multicolumn{7}{|c|}{ Table 1. The results of statistical analysis } \\
\multicolumn{7}{|c|}{$\begin{array}{l}\text { Pediatric Group } \\
\text { (Group 1) } \\
\text { ( } \%)\end{array}$} & $\begin{array}{l}\text { Adult Group } \\
\text { Group 2) } \\
n(\%)\end{array}$ & p Value \\
\hline Cajal Cell & - & $1(10.0)$ & $5(11.9)$ & 1.0 \\
\hline & + & $5(50.0)$ & $23(54.8)$ & 1.0 \\
\hline & ++ & $3(30.0)$ & $8(19.0)$ & 0.740 \\
\hline & +++ & $1(10.0)$ & $6(14.3)$ & 1.0 \\
\hline Elastin & & $1(10.0)$ & $7(16.7)$ & 0.970 \\
\hline Fibrosis & & $5(50.0)$ & $10(23.8)$ & 0.210 \\
\hline $\begin{array}{l}\text { Collagen } \\
\text { Type 3 }\end{array}$ & & $2(20.0)$ & $6(14.3)$ & 1.0 \\
\hline P= Chi-square test & & & \\
\hline
\end{tabular}




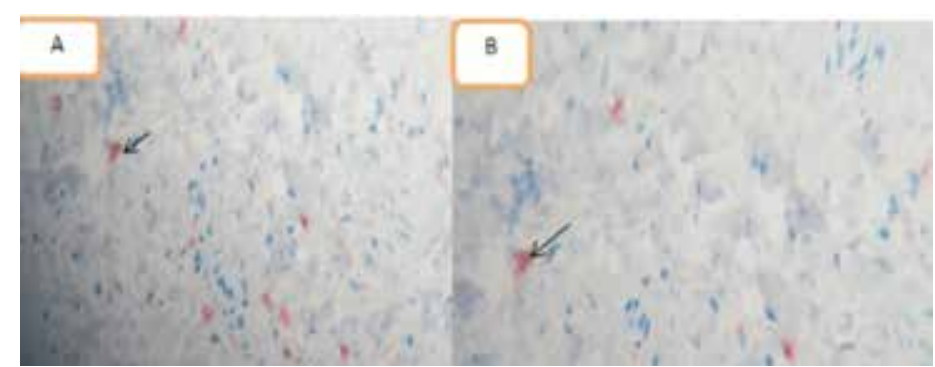

Figure 1. A) Immunoperoxidase $\times 400 \mathrm{Cd} 117$ positive cajal cells. In pediatric group of a male patient age $1, B$ ) In Adult group of a male patient age 38

In a study by Star et al. comparing normal UPJ segments and UPJO segments, it was reported that in UPJO the lamina muscularis was thicker, there was a greater amount of interfascicular and intrafascicular collagen and more deterioration in elastin fibres (8). Yoon et al. compared normal UPJ segments with UPJO segments from both paediatric and adult patients and the amount of collagen was found to be high in both groups and at a significantly high rate in the adult group (9). Masashi et al. also compared normal UPJ and UPJO segments and showed an increased amount of collagen. It was suggested that due to the impaired innervation in the area, smooth muscle cells had become atrophied and been replaced by collagen, which caused both a functional and anatomical obstruction (7).

In the current study, there was no difference between the paediatric group and the adult group in terms of the amount of collagen type 3. This can be considered to be due to collagen accumulation not forming secondary to the obstruction as the pathology in congenital uteropelvic junction obstruction is from birth.

In a study by Özel et al. (10), in which normal UPJ segments were compared with UPJO segments, fibrosis was found to be greater in UPJO patients. In the current study, both groups had congenital UPJO and there was no control group of normal UPJ segments. It is our opinion that greater fibrosis can be seen in patients with UPJO but that this change has been present from birth and has not developed at a later date.

That cajal cells in the UPJ provide peristalsis through electrical waves in the smooth muscle cells was first defined by Solari et al. $(6,11,12)$. There are many studies in literature which have researched cajal cells in the histopathological examination of congenital UPJO segments. In a study by Solari et al. comparing normal UPJ segments with UPJO segments, the number of cajal cells was found to be significantly low in the UPJO segments and therefore in that patient group peristalsis was inadequate in that region as there was an insufficient number of cajal cells, which then resulted in the development of obstruction (6).

In contrast, Koleda et al. determined a higher number of cajal cells in UPJO segments than in normal UPJ segments. This was explained by an increase in the number of cajal cells in the obstruction area to compensate for the obstruction. In the same study, the number of cajal cells were seen to decrease with increasing age in a paediatric group (13). Kuzgunbay et al. (14) suggested that there was an increase in the number of cajal cells in the early stages of an obstruction, but in the late stage, the cajal cell number decreased. In contrast to the studies of Koleda and Kuzgunbay, the results of the current study showed no decrease with age in the number of cajal cells. No statistically significant difference was determined between the two groups of the current study in respect of the number of cajal cells.
In conclusion, the results of this study have shown that the histopathological impairment in the uteropelvic junction formed from congenital UPJO, has not developed secondary to the obstruction and there is no change in the histopathological structure over time. In the current study, the number of cases was low and there was no control group for evaluation of normal UPJ segments. Therefore, there is a need for further studies on this subject with a greater number of cases and including a control group.

\section{Conflicts of Interest}

There are no conflicts of interest.

\section{References}

1. Wang $Y$, Puri $P$, Hassan J, Miyakita $H$, Reen DJ. Abnormal innervation and altered nerve growth factor messenger ribonucleic acid expression in ureteropelvic junction obstruction. The Journal of urology 1995;154:679683.

2. Osathanondh V, Potter EL. Development of Human Kidney as Shown by Microdissection. lii. Formation and Interrelationship of Collecting Tubules and Nephrons. Archives of pathology 1963;76:290-302.

3. Nixon HH. Hydronephrosis in children; a clinical study of seventy-eight cases with special reference to the role of aberrant renal vessels and the results of conservative operations. The British journal of surgery 1953;40:601-609.

4. Whitaker RH. Clinical assessment of pelvic and ureteral function. Urology 1978;12:146-150.

5. Murnaghan GF. The dynamics of the renal pelvis and ureter with reference to congenital hydronephrosis. British journal of urology 1958;30:321329.

6. Solari V, Piotrowska AP, Puri P. Altered expression of interstitial cells of Cajal in congenital ureteropelvic junction obstruction. The Journal of urology 2003;170:2420-2422.

7. Murakumo $M$, Nonomura $K$, Yamashita $T$, Ushiki $T$, Abe $K_{1}$ Koyanagi T. Structural changes of collagen components and diminution of nerves in congenital ureteropelvic junction obstruction. The Journal of urology 1997;157:1963-1968.

8. Starr NT, Maizels M, Chou P, Brannigan R, Shapiro E. Microanatomy and morphometry of the hydronephrotic "obstructed" renal pelvis in asymptomatic infants. The Journal of urology 1992;148:519-524.

9. Yoon JY, Kim JC, Hwang TK, Yoon MS, Park YH. Collagen studies for pediatric ureteropelvic junction obstruction. Urology 1998;52:494-497

10. Ozel SK, Emir H, Dervisoglu S, Akpolat N, Senel B, Kazez A, Söylet Y, Çetin $G$, Danişmend N, Büyükünal SN. The roles of extracellular matrix proteins, apoptosis and c-kit positive cells in the pathogenesis of ureteropelvic junction obstruction. Journal of pediatric urology 2010;6:125-129.

11. Huizinga JD, Thuneberg L, Kluppel M, Malysz J, Mikkelsen HB, Bernstein A. W/kit gene required for interstitial cells of Cajal and for intestinal pacemaker activity. Nature 1995;373:347-349.

12. Thomsen L, Robinson TL, Lee JC, Farraway LA, Hughes MJ, Andrews DW, Huizinga JD. Interstitial cells of Cajal generate a rhythmic pacemaker current. Nature medicine 1998;4:848-851.

13. Koleda P, Apoznanski W, Wozniak Z, Rusiecki L, Szydelko T, Pilecki W, Polok M, Kalka D, Pupka A. Changes in interstitial cell of Cajal-like cells density in congenital ureteropelvic junction obstruction. International urology and nephrology 2012;44:7-12.

14. Kuzgunbay B, Doran F, Bayazit Y, Turunc T, Satar N, Kayis AA. The effects of ureteral obstruction on Cajal-like cells in rats. Journal of pediatric urology 2009;5:269-273. 